\title{
Economics Of Food And Leisure Services
}

\author{
*Alexandru Trifu,Moise Cîndea \\ *trifu.alex@gmail.com
}

\begin{abstract}
Important in this paperwork is to underline the significance and the role of one of the economic niche domain, that is food and leisure. We think that this name, evoqued in the title, is more appropriate, than catering, to design the economic process of providing, transformation (even production) and consumption of food, especially within firms, corporations, in the benefit of theirs employees. Therefore, we've analyzed some theoretical and practical aspects of this kind of Economics. Because, it's indeed an aspect of Economics, regarding the factors of production (on a larger scale, the resources), the production and preparation of different meals and, finally, meet the demand required by the people who intend to mix the food pleasure with work activities.The practical example is from Romania's services, which domain is not enough developed and there are many things, especially of qualitative order, in order to improve catering or food services within the entire Romanian economic system.
\end{abstract}

Key words:catering, business environment, SWOT analysis, culinary products, consumer satisfaction.

\section{Introduction}

General Approaches: The economic science has incorporated elementsof philosophyfrom the seventeenthandeighteenthcentury(especially from theBritishJohnLocke, David Hume, John Hobbes), which became starting pointsinshaping the neweconomic science.The clear specification of the economics' matter of study comes precisely from this period: theuseofscarce resourcesin order to meetcertainset goals and certain expressed needs.These desiderates, which economics as a science was supposed to fulfill, are best expressed by the subtitle ofJ-B. Say's fondamentalWorks,in fact the firsttreatyof classical Political Economy, entitled, Traitéd'économie politique, ou simple exposé de la manière dontse forment, se distribuent et se consomment les richesses".We have insisted upon theauthor mentionedabove and the titleof hisreference workbecause, in theAnglo-Saxonperimeter, during the twentiethcentury,but especiallyduring the postwar period, the economic sciencehas evolvedandis evolvingunder the name ofeconomics, translatableasthe theory of studying themeansof meeting certain goals, those regarding the solving of problemssuch as: what toproduce?, Howtoproduce?For whomtoproduce?Being fundamental. The termcompelled recognition and acquired globalopenness andacceptancebythe capitalworkof American ProfessorPaulAnthonySamuelson, entitled"Economics", which was publishedin 1948 andenjoyed manyreprintsandtranslations inover40 languagesaround the world ${ }^{1}$.

In a market economy, companies compete in thesale of their goods andservices.Tosuccessfully facecompetition, their mainconcernis tomeetconsumer interests.As a result, they will striveto produceonly goodsthat meetcustomer requirementsin the most suitable way. Thus, companies that launchnew productsor improvethe quality oftheir existing productsare likely toearn ahigher marketsegmentoverthe others, which willhave to reduceactivity.The wordcateringcomes from the nouncate. It was firstly given the meaning ofpurchase andthenthemeaningofpurchased food. Afterwards, they obtained the verb to cate= todressandthenthenouncaterer=personprovidingsuppliesfora household orcluborproviding the foodnecessary for aholiday.Thissystem arosein the largeU.S.urban areas, andthenexpanded rapidlyineconomically developedcountriessuch asEngland, Franceand Sweden. Thecatering mainly addresses collectivecustomers(school canteens, hospitals,military and aviation units, self-servicerestaurantsorfast foodestablishments) ${ }^{2}$.The analzyed systemallowstheconcentration of productionin large unitswith multipleadvantages:

- The increase of the level ofmechanizationofprimaryprocessing operations;

\footnotetext{
1 Trifu, (2006) Essay regarding a panoptic of organic synapses of Economics, Performantica Publishers, Iasi, 10-20.

${ }^{2}$ Brăiescu, (1997). Guidelines on the assortment structure and efficiency of catering products at global level (the result of his PhD thesis), Bucharest, 27.
} 
- The application ofmodernmethodswith ashort duration ofheat treatment;

- Preservation andconversionunder appropriate conditions;

- The possibility to efficiently increasethe number of assortmentcombinations;

- Ensuringhygiene by implementing modern methods, thus resultingsalubriousfinished goodswithhighnutritional value.

In order to be effective, anyfood providing system requiresthe completionof fivekeypoints, which ensures the finality andsuccess of the activity:Identifying theconsumer(customer type, needs); Formulating the policy of thecatering unit (organization chart, menus, professional standards,economic situationanalysis, SWOT analysis, stafftraining, socio-cultural and environmental impact);

- Interpreting the demand;

- Using the facilitiesprovided by technology;

- Analyzing themost suitable supply.

The premises of a successful food providing system activity 3 :A catering activity is successful if it has the following characteristics:

- Largeproduction capacities with continuous fabricationlines.

- Mechanization andautomation of thetechnologic process.

- Application oftraditionaland newtechnologies.

- Achievinga high quality ofthe finished productthrougha rigorous compliance with theworking conditions.

- Restrictingthe rangeof food additives.

- The superiorrevaluation of the resourcesof raw materialsinto products.

- Ensuringmaximum satisfaction.

- Implementing newappropriatewrappingand packaging systems.

- Aperfectly elaboratedcoldchain(regarding transportationandstoragespace).

- Adequate thawingand heatingsystems, resulting into salubrious finishedgoods, withhighnutritional value.

Theeconomicoutputof thecateringsystemis defined as anyready-madefood dish preparedinspecializedindustrialsections, keptfor a longer or shorter periodinspecialconditionsand commercializedbydifferenttypes ofcateringunits. Suchdishes become the dailymenusinrestaurantcanteens, self-servicepermanent units, restaurants andfast foods.The cateringproductcan be definedasa mixture ofcomponentsdosed in certainproportions,industriallyprocessedandpreserved bydehydration, freezing andthermalstabilization.Tourism developmentand the deepeningof the eatingaway from hometrend have contributed to thepermanentdemand for culinary productsand to anunevendistributionof the demandduring the day, withlarge differences betweenthe maximumand minimumdemand.

\section{Inside the Problem}

In the last two decades, the food-providing services, in the tourism industry has significantly grown in England and in other Western countries, reaching 4,000,000 meals per year ${ }^{4}$.Themainaim of thefoodproviding system is to solve the production deficienciesofclassiccuisines, not only byproducing intensively requiredfinisheddishes (ready for consumption), but alsosome ready-to-eat housewife-type products, or,most often,the centralized processingof vegetables andmeat, which is asolutionpracticedin our country.The transition to the catering systemis doneonly after certaintechno-economic competent studies, which become the basisof thesolutions chosenas being the mosteffective.Thusa new divisionof laboris obtained within thesystem of production, distributionand servingculinary dishes: the centralkitchenfocuses exclusively on producing the dishesandsupplyingtheretailunits, while thecateringunitsdeal withstock depositingandconverting the dishesbasedon consumer demands.Characteristic to industrialcateringis the phenomenonof centralizingthe operationsrunfromthe raw materialto the finished productand the methods of preserving thefinished products.

${ }^{3}$ Negrea \& Pîrvulescu, (2000). Food.Catering, Eurobit Publishing house, Timişoara, 55

${ }^{4}$ Stanciulescu, Gabriela (2003) Management of tourism operations, All Beck Publishers, Bucharest. 
The commercial cateringrefers to organizing the sale of the industrial cateringproduct. The link between industrial catering andcommercialcateringisdistribution.Some countriesthat uselarge-scalefoodproviding services (USA,Sweden) show somebasic principlesin this area:the useof aperfectly elaboratedcoldchainandthe use of specialized insulatedtransportcontainers; the rationalization ofwholesaletradeandthe development ofcold department stores locatedin consumption centers as to beaccessibleforsale;Equippingthe consumptioncenters with owncontainers.Commercial catering, on the other hand,solves the problems regarding thesupply and food preparation in the largekitchenswithin hospitals, canteens andbarracks.Charitycatering is the mainnon-commercial sectionof the cateringindustry. Thissector includescateringinnursing homes,retirementhomes, schools and orphanages and is in the category of social catering that is hospitality industry.A comparison of the costsoftheclassiccuisineand that usingfrozenmealsindicatessavingsof about $65 \%$ regardinginvestments andup to85\%regarding wages.For designingnewservices for food-providing units, it is necessarytostudythe structure of thefutureclientsby age, sex, income and occupation.It is estimatedthatcateringproductscan and shouldaddressbothnutritional needsas well as thoseneedsinfluenced byeconomic, socio-cultural and psychological factors.The nationallyand internationallyrecorded impulseafter 1990 regarding the diversificationof the catering productoffer, especially as a consequence ofthe benefits regarding time andmoney savingimplied bytheir consumption, confirmsthe recognition ofthese products' superiority along withputting behind the doubtsregarding them.Cateringproductscontribute tothe effectiveuse of available resources andto the diversificationof the range offood products in order to cover the real needs of theconsumers.

Extending the fabrication of catering productsis possible becausethereare or can be created the necessarytechnicalconditions, adequate resourcesof raw materials can be provided, there is growing demandin the context of an increasing level ofemploymentand thereforeof the reduction in the time forpreparingandservingfood.Potential consumersareall thoseconsumersthat are receptive tonew, willingto give upthe idea oftraditional, replacing even partiallythe traditionalcuisine.The categories of consumerswilldifferentiatemainlyfrom the psychological point of view, thereluctancetonew, to change,the degree ofconservatismregarding traditions, habitsandfoodpreferences.Within the catering products' market, thesector made of collectiveconsumers is the most important.Cateringproductsare more and morerequested byindividual consumers, in order to make variousmenusfor celebrations, receptions or picnics. The quality of thesedishes, the way they are presented and served are aspects that favor them againsttraditionalculinaryproducts.More andmore consumersshow a marked preferenceforfrozenproducts. The results ofa surveycarried out in the formerWest Germanyshowed that $60 \%$ of thecitizens livingin householdsofone ortwo peoplewould not wantto be deprived of these products under any circumstances. At the end of a working day, they would like to eatfast, yet without giving upthefreshnessandfull nutritional contentof the products.

According tothecompanies in the field, in the absence ofstatistical data on theRomaniancatering market potential, in the context of 22 million inhabitants, outofwhich fivemillionare active people, at an averageamountof 20 lei per day spentfor food, this wouldtranslate intorevenuesof 100 millionleiin oneday forthe cateringcompanies. More than 200catering companies operate on the domesticmarket,outof which80in Bucharest alone.Culinary products are promoted by the menu, whose presentationinvolves the followingmethods 5 :

- Visualpresentation.The visualpresentationof goodsand culinary dishesmeans their presentation underthe form ofa mini-exhibition orof an exhibition on specially designed stalls within the restaurant, onpresentationcarts which are specific to the ranges of goodspresented orinspecialshowcases;in allthesecases, the dishesmust bepresented in anaesthetic, pleasant andinvitingmanner and must meetallthe requirements regarding sanitaryhygiene. Forpresentation,the dishesshould meetallaesthetic, gastronomic and technicalqualities, wearing a labelwith explanations regardingthe nameof the product anditsprice.

- Writtenpresentation.This method ofpresenting goods and dishes within gastronomicunitsmeanspresenting them eitherdaily, through the "menu list" (made forall the stages ofthe day), or under the form ofoccasionalorpermanent"commercial advertising" (throughleaflets, press, magazines, posters or billboards). Allthese methods ofpresentation mustbe usedin an aestheticgraphical form, with exactdataregardingthe place ofaction and particularly regardingthe existence ofthe productslistedin the add

${ }^{5}$ Brăiescu, (1997). Guidelines on the assortment structure and efficiency of catering products at global level (the result of his $\mathrm{PhD}$ thesis), Bucharest, 54 
The listmust containthe following sequenceofdatapresentation6: date, month, year,goods anddishes determination, weightandmeasure, sale price, the stage of the day for which it is prepared (breakfast, lunch, dinner), the signature of the head of the unitand ofthe headchef, quality certification. The dishes are placed in groupsas follows:

- cold and hotsnacks;

- minutes;

- $\quad$ hot drinks for breakfast;

- $\quad$ liquids(soups, creams, borsch);

- fish dishes;

- $\quad$ vegetable dishes with or without meat;

- $\quad$ steakspecialties, vegetableside dishes;

- salads;

- desserts;

- Soft andalcoholic drinks.

Televisionpresentation. This methodis performed through special programs, within the internaltelevision circuitof the unit.The televisionmonitorsare locatedinthe eating room. All the goodsandculinary dishes, which are prepared and served by the unit,arepresented through a nicedescriptioncarried out bysectorspecialists.

- Electronic presentation (Internet), through which are listed, in real timeandwith plenty ofinformation anddetails, the goodsand dishes thatcan be offereddaily; this can also be done for the stages of the day on electronic displaypanelsinstalled in the eating rooms, observing the aesthetic principlesin achievingthe display.These presentations may be periodicorcontinuous, through thecontrol panel, whichhasdirect relationswithallunit sections.

- $\quad$ Oraland mixed presentation. Such a presentationis done by theworkerwaiterby words, directly at the table,and is combined withthe writtenpresentation(menu list) andthe visual presentationof the plateauofdishes andof the beverages, followed bya brief descriptionof the characteristics.

They say thefoodcookedby someone elseis alwaystastier;restaurantsoffer thisluxury, but lack home comfort.What happenswhen you do notwantto leaveyour home, the place where you feelbest, oryou wantthe partyto beyours alone,withoutthe looks ofsome strangerswho you may notwantto share yourprivacywith.The answerto this questionis simple: hirea catering company.Let us consider arestaurant,call it, B", from aless developedregionof Romania (such as Moldavia), which hasconstantly suppliedthe companies:Alpha, Beta, and Omega with catering products.The restaurantwasable toprovide 700dailyportions, of which 680forOmega, 15 for Beta and 5 for Alpha.
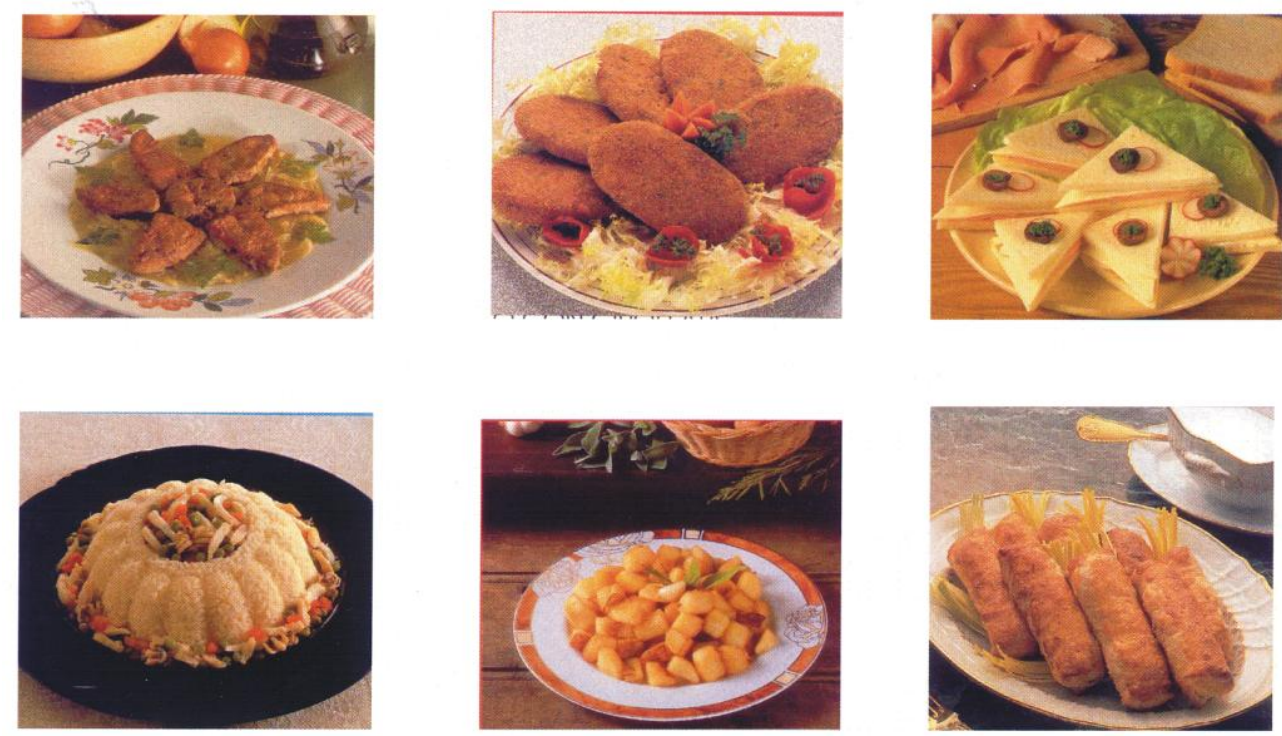

${ }^{6}$ Negrea \& Pîrvulescu, (2000). Food.Catering, Eurobit Publishing house, Timişoara, 45 
The catererof restaurant, B" is the one planning themeals forvariousevents, he hasspecialskillsthatturn him intomore thana cook-waiter (his basic profession), and in facthe is thehead of theroom. The catererknows allthe rules offood preparation, he isconcerned withallthe specialclaimsrelated to aparticulardiet, he knows the entire planning activity(regarding supply-sales),documentsallthe details related to theimplementationof an orderorsupply and also hasgreatorganizationalcapacity.There are a fewqualitiesthat acaterer must not lack: marketing knowledge, communication skills, resourcefulness, punctualityandthe abilityto workunder deadlines. Thetwocaterers of the restaurantdo not lack these qualities; they areprofessionalcatererswhose activityis successful in the context of thecompetitivemarket.Given thattype of food service, which issuch an important part of therestaurantactivity,bringingthe company a profit that is not negligible, the managementhasdecidedto use a strategy in order to developthis activity in the future.The development strategy is used in this respect ${ }^{7}$.

The development strategyoccupies, amongst others, an essential place given its complexityand importanceto the economic activity. The development strategyis elaborated on the grounds of the following elements:

- economicor businessenvironment

- internal situation

- Company's aim

Elaboratingthe development strategyrequires going through the followingstages:

- Formulating themission: developing the cateringactivity within the restaurantBelvedere

- Highlightingthe weaknesses andstrengths: they can be found inthe conclusions of the paper

- findingopportunitiesand threats

Opportunities:

- Diversification ofproduct range

- Winning newmarkets and implicitlynew customers

- Increasingbusinessprofitability

Threats:

- The level of demand

- The structure of consumption priorities, thus losing thetraditionalistcharacterof the restaurant

- Identifyingthe firm's placein the businessenvironment.Forthis,it is necessaryto identifythe internal and external factorsthat determine thecompany'sshortcomings.Internal factors:

- $\quad$ Financialand exceptional incomeregression

- $\quad$ External factors:

- $\quad$ Competitors

Consumer behavior, lack of education inacceptingcateringculinaryproductsinstead ofclassic culinaryproducts.

- Settingobjectives andstrategicoptions:

- Assimilatingnewculinary products

- Improving the oldculinary productsby ahigh qualityof the raw materials

- Broadeningthe cooperation withnew companiesby signing contracts

\section{Conclusion}

The alimentation of thefutureas well as relaxation andrecoverypossibilities requireculinary productsthat are as ecological as possible and the cateringsystem, paying attention tothe current view onnutrition,meetsthe demandsof the modern manlivingina society ofcontinuoustransformations.

- The production of cateringdishes iscontinuouslydeveloping and diversifying, based on the scientificandtechnologicalachievementsinfood preparation,obtainedbycarrying outnew research, by extending the rangeof raw materials usedandtheranges of dishes.

\footnotetext{
${ }^{7}$ For detailed elements of management and marketing in catering field, see Babaita, (2010) Catering as a business, Mirton Publishers, Timişoara.
} 
- The increasing level of employmenthas increasedthe eatingaway from hometrend, thedemand forprecookedproducts andfinishedculinary products. The unevenlymanifested demand during the day, the weekand seasonshas ledto the development ofthe cateringsystem, which providessignificant benefitsfor bothcustomersandthe unit.

- The quality ofcateringproductsis largely influencedbythe freshnessof the raw materials.

- In assessingquality, it is necessary to take intoaccountthe benefits ofthecateringproducts in the sense that their innocuousness is ensured.

- A decisive role forthe success ofthe systemfalls on the promotion of thecatering products on the market.

- Food-providing services find theirs applicabilityin the collective alimentation in enterprises or hospitals as an attempt to correct the weaknessesinterms of quality, range and price. This applicability ought to beencouraged.

- Fabricatingculinaryproductsin thecateringsystem assuresa higher economic and social efficiencycompared to the traditional culinaryproduction.

- The links between resources------food preparation and assortments created---------meeting the consumer's preferences and that is the core of considering food and leisure services as a niche market within Economics commerce.

Those whomanaged to survivetheseobstacles are now facing the needto be in line withtheEuropean Union standardsregardingequipment,kitchenhygiene, transport, storage, etc. In addition, from now on, catering companieswill haveto face amoreexperiencedcustomer,be it a Romanian company, which hasalreadylearnedthese practices, or a foreigncompanyexpectinga level of the servicesas highas that fromoutside Romania.Customersknownow what they want and what toask for sort them out, on the principlethat the demandcan and must influence the supply.

\section{References}

Băbăiţă, C. (2010). Catering as a business, Mirton Publishers, Timişoara.

Brăiescu, L. (1997). Guidelines on the assortment structure and efficiency of catering products at global level the result of his $\mathrm{PhD}$ thesis, Bucharest;

Negrea, A.\&Pîrvulescu, L. (2000). Food, Catering, Eurobit Publishing House, Timişoara.

Stănciulescu, G. (2003). Management of tourism operations, All Beck Publishers, Bucharest.

Trifu, A. (2006). Essay regarding a panoptic of organic synapses of Economics, Performantica Publishers, Iasi. 